\title{
ヤリの弾性を考慮に入れたやり投げの力学的解析
}

\author{
前田正登1) 野村治夫1) \\ 社 本 英二2) 森脇 俊 道2)
}

\section{Dynamic analysis in javelin throwing considering javelin elasticity}

\author{
Masato Maeda ${ }^{1}$, Haruo Nomura ${ }^{1}$, \\ Eiji Shamoto ${ }^{2}$ and Toshimichi Moriwaki ${ }^{2}$
}

\begin{abstract}
The present paper presents a new sensor for measuring six components of force and two components of deflection applied to a javelin. Two types of javelin differing in stiffness were thrown by three javelin throwers. The force and the deflection applied to the javelin during throwing were measured to analyze the throwing motion and the dynamic behavior of the javelin.

The major results obtained were as follows;

The force in the axial direction of the javelin falls or remains unchanged temporary just before the value reaches its peak during release. The torque around the axial direction of the javelin tends to fall to a minimum value and then reach a peak. The change of force in the lateral direction of the javelin is roughly dominated by that in one direction.

The deflection of the javelin during throwing is not one-directional as reciprocation, but multidirectional. In order to consider the force applied to the javelin and the deflection of the javelin form the viewpoint of the thrower, it is necessary to consider the rotation around the axial direction of the javelin as well.

The value of deflection of the javelin is affected by its stiffness. However appears that the stiffness dose not affect the values and patterns of force and torque applied to the javelin.

Key words: javelin throw, dynamic analysis, force applied to javelin, javelin elasticity, throwing movement
\end{abstract}

(Japan J. Phys. Educ. 42: 270-282, November, 1997)

キーワード：やり投げ，力学的解析，ヤリに加わる力, ヤリの弾性、投げ動作

1. 緒言

近年，やり投げに関して多くの研究が多角的に 進められ，それぞれが競技成績の向上に貢献して きた．中でもヤリのリリース時における最適投射
初期条件に関する研究は, 測定手法の発達に伴い 数多く見られるようになってきた $7,8,14,15)$. 投射 後のヤリの弾道（飛距離）はリリース時の投射初 期条件によってほほ決定される8)ので，飛距離の 向上を目的とするならば，ヤリの最適投射初期条 件を検討することは有意義であろう。しかし，そ の投射初期条件は，例えば初速度が投げ動作中に
1）神戸大学発達科学部 干657 兵庫県神戸市灘区鶴甲 3-11

2) 神戸大学工学部 干657 兵庫県神戸市灘区六甲台町 1
1. Kobe University, Faculty of Human Development, 3-11 Tsurukabuto, Nada, Kobe 657

2. Kobe University, Faculty of Engineering, I Rokkodai, Nada, Kobe 657 
ヤリに加えられた力の積分から求められるよう に，投げ動作中に競技者がヤリに加えた力によっ て生じる一つの結果と見ることができる，このよ うに，投げ動作中に競技者がヤリに加える動的な 力は, 最適投射初期条件や最適な投げ動作の検 討,さらには最適な動特性を持つヤリの開発など に関わる極めて重要な物理量であるといえる.

やり投げ競技に掞いて，ヤリはたわみを生じて 投射されていることが観察されている5,10,14,16). 競技者もヤリのたわみは認識して抢り，飛行中の ヤリのたわみ（振動）が競技成績に少なからず影 響するというシミュレーション結果6)もある，元 来, ヤリは弾性体であり, ヤリによって硬さ（正 確には剛性, 変形のしにくさ）は異なる11)。し たがって，ヤリにたわみが生じることは必然的で あり，飛行への影響だけでなく投げ動作に及ほすす 影響もあわせて検討することが競技成績向上のた めには不可欠であると考えられる.

本研究では，ヤリの弾性を考慮した上でヤリに 加わる力を測定し，ヤリに作用する力・トルクと いう観点からやり投げを力学的に解析するととも に，ヤリの弾性が投げ動作に及ほす影響を検討す る。

\section{2. 研 究 方 法}

\section{1 実験用ヤリと 6 軸カセンサ}

ヤリに加わる力及びヤリのたわみを測定するた めに，独自に開発した 6 軸力センサ13)を装備し たヤリを使用した：このカセンサは，ヤリに加わ る力 $(\mathrm{Fx}, \mathrm{Fy}, \mathrm{Fz})$ とトルク $(\mathrm{Tx}, \mathrm{Ty}, \mathrm{Tz})$, 及 びヤリのたわみ（Dy, Dz）を測定することがで きる（Fig. 1)。ヤリ本体はカセンサを装備する ために，通常の競技用ヤリとは若干外観が異なる が，ヤリとしての諎特性はできる限り変えないよ うに配慮している（Fig. 2).

本研究では,やり投げの投げ動作とヤリの剛性 の相互間の影響にも着目するので，剛性が異なる ように改造した 2 本のヤリを用意した. 2 本のヤ リは長さ, 質量, 重心位置, グリップ位置などに は差が生じないように配慮し，かつ，ヤリの剛性 に差が生じるように，一方のヤリにはグリップ部

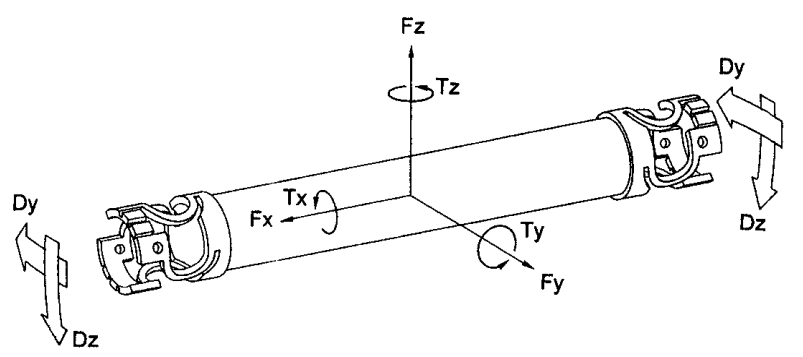

Fig. 1 Schematic illustration of 6-axis force sensor.

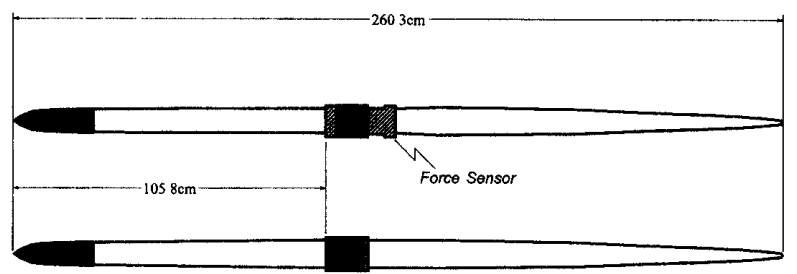

Fig. 2 Javelin equipped with force sensor.

とヤリの振動の節（1 次モード）との区間に直径 $4 \mathrm{~mm}$ の穴を160力所あけて㓮性を落とし（Javelin-A), もう一方のヤリは, 逆に振動の節と両端 部との区間の肉厚を削り落として剛性を上げた (Javelin-B)．これにより，2本のヤリは質量や 重心位置などの静特性に大差がなくても, 静剛性 のほか共振周波数などに異なる動特性を持つこと になる(Table 1 参照)．ただし，この 2 本のヤ リは，通常の競技用ヤリに比べるとカセンサがヤ リの中央部に組み込まれているため，重心を通る 短軸まわりの慣性モーメントが小さくなってい る.

\section{2 実 験}

被験者は, Table 2 に示す男子やり投げ競技者 3 名である。な抢, 被験者は全員右利きであっ た。

2 種類のヤリをやり投げ競技者 3 名にそれぞれ 3 回ずつ投げさせ，Fig. 3 に示すような力測定シ

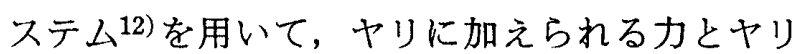
のたわみを測定した，同時に，助走開始からヤリ のリリースに至るまでの動作を高速度 VTR （HSV-400: nac 社）を用いて200 fps の撮影速度 
Table 1 Characteristics of the javelin with force sensor and ordinary javelin

\begin{tabular}{l|ccc}
\hline & Javelin-A & Javelin-B & Supreme \\
\hline Length $(\mathrm{cm})$ & 260.3 & 260.3 & 261.5 \\
Mass $(\mathrm{g})$ & 811.6 & 813.5 & 810.8 \\
Center of gravity ${ }^{\dagger}(\mathrm{cm})$ & 105.9 & 105.8 & 105.6 \\
Grip $^{\ddagger}(\mathrm{cm})$ & 120.4 & 120.4 & 120.6 \\
Moment of inertia & & & \\
$\quad$ Short axis $\left(\times 10^{3} \mathrm{~kg} \cdot \mathrm{cm}^{2}\right)$ & 3.21 & 3.07 & 4.11 \\
$\quad$ Long axis $\left(\mathrm{kg} \cdot \mathrm{cm}^{2}\right)$ & 1.39 & 1.33 & 1.28 \\
Compliance $\left(\times 10^{-3} \mathrm{~mm} / \mathrm{N}\right)$ & 73.8 & 68.8 & - \\
Resonant frequency $(\mathrm{Hz})$ & 23.7 & 25.6 & 25.9 \\
\hline
\end{tabular}

$\uparrow$ Distance from tip to center of gravity.

$\ddagger$ Distance from tip to end of grip.

If Moment of inertia on center of gravity.

$\S$ Static compliance.

で収録した。な㧍，被験者にヤリを握らせる直前 に，センサ部（グリップ部）に触れずにヤリを水 平に支持し，その時の出力を一旦すべて 0 とし てから測定を開始した。

カセンサからの信号はコネクタを介して取り出 されるため，ヤリのリリース直後にはコネクタが はずれて測定不能になる.8軸分のブリッジ回路 からの出力はストレインアンプ (DMP-711B : 共和電業）を介し，高速度 VTR からのパルス信
Table 2 Charcteristics of the subjects and their best records in javelin throw

\begin{tabular}{ccccc}
\hline Subject & $\begin{array}{c}\text { Height } \\
(\mathrm{cm})\end{array}$ & $\begin{array}{c}\text { Weight } \\
(\mathrm{kg})\end{array}$ & $\begin{array}{c}\text { Age } \\
(\mathrm{yrs})\end{array}$ & $\begin{array}{c}\text { Best record } \\
(\mathrm{m})\end{array}$ \\
\hline M.M & 183.0 & 93.0 & 32 & 65.68 \\
Y.M & 173.0 & 85.0 & 28 & 74.38 \\
K.K & 181.0 & 85.5 & 23 & 72.70 \\
\hline
\end{tabular}

号とともに A/D 変換器 (PS-9351: TEAC 社) を経てコンピュータに入力される。な拈，このと きの $\mathrm{A} / \mathrm{D}$ 変換のサンプリング周波数は $1 \mathrm{kHz}$ と した.

カセンサから出力される測定データはひするべ クトルであり，各軸間の干渉量を含んでいるの で，補正するための行列を乗じてヤリに加わる 6 成分の力と 2 成分のたわみに変換した ${ }^{12,13)}$.

\section{3. 結果と考察}

3 名の被験者による 6 回の試技のうち，最も投 てき距離の大きかった試技を Javelin-A, JavelinB それぞれ対比して Fig. 4.1-Fig. 4.3に示す. 図 中の* 印及び数值は, 各軸の絶対值が最大のとき の值を表記している．また，（a）から(g)の人物 像は高速度 VTR に基づき，それぞれの瞬間での 投げ動作のフォームを示したものである。横軸は

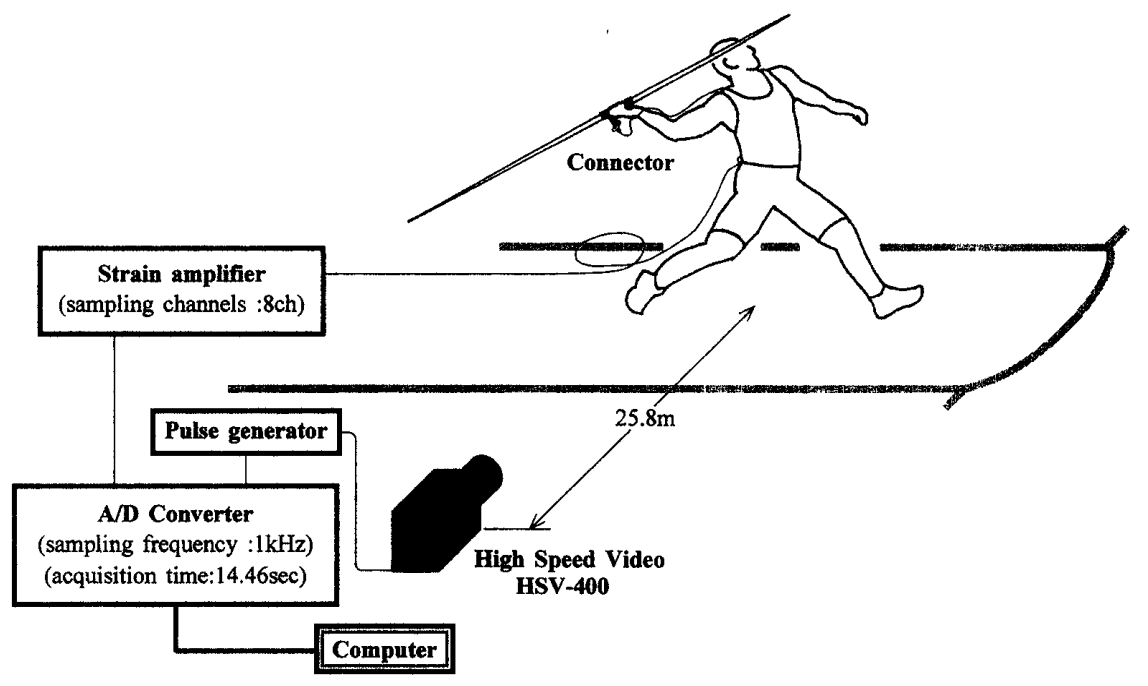

Fig. 3 Schematic illustration of experimental setup. 

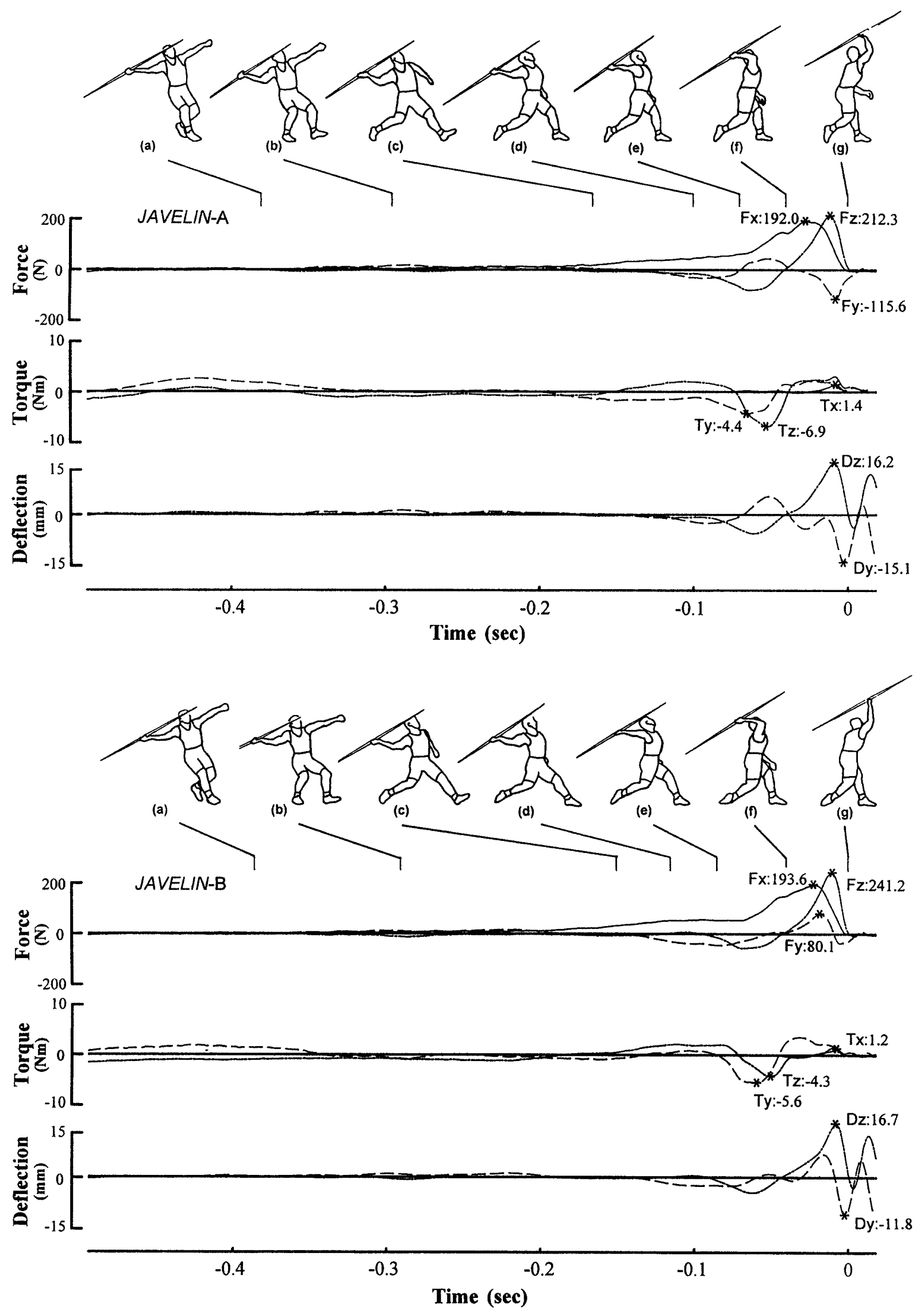

Fig. 4.1 Measured forces in javelin throwing. (Subj. M.M) 

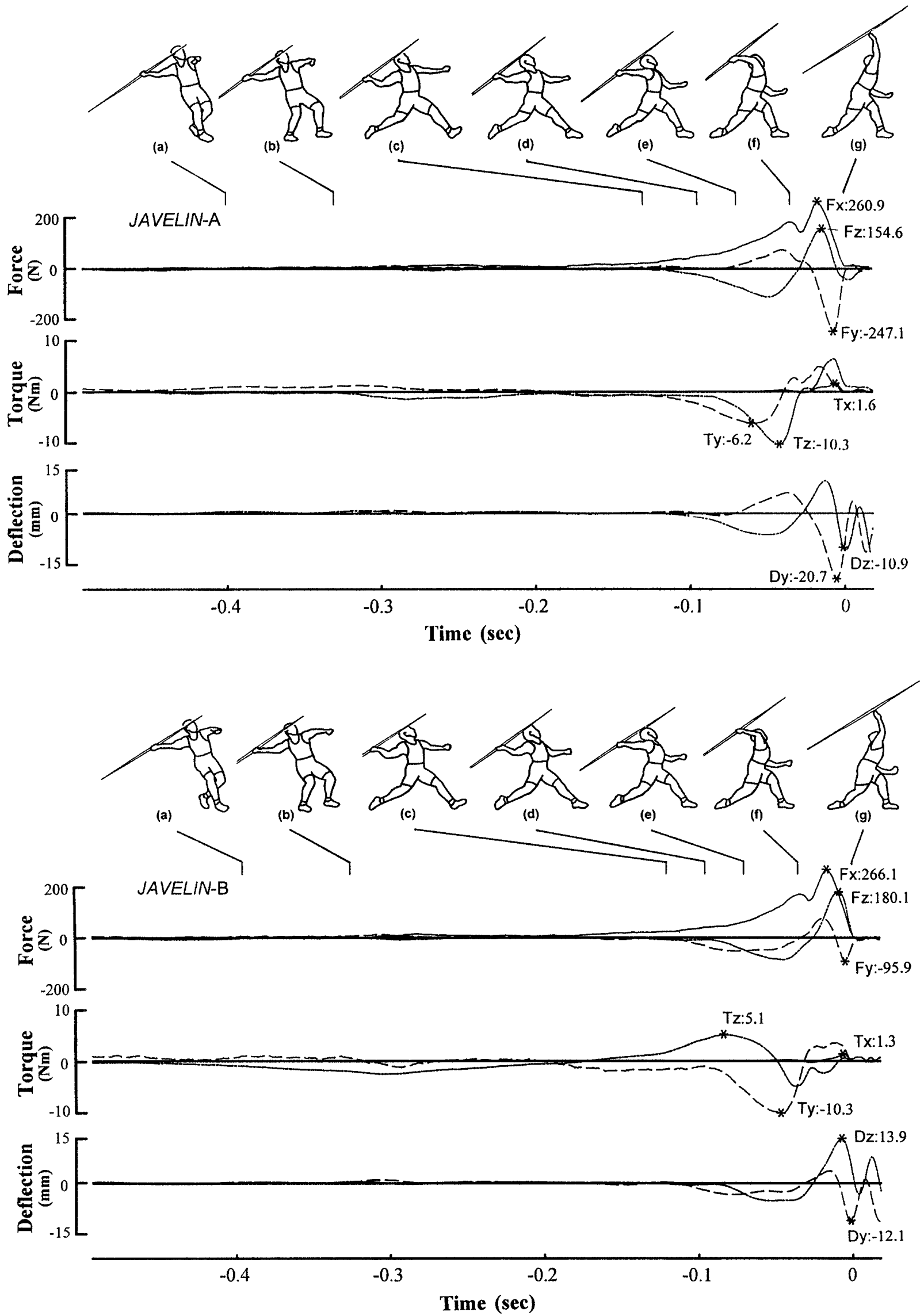

Fig. 4.2 Measured forces in javelin throwing. (Subj. Y.M) 

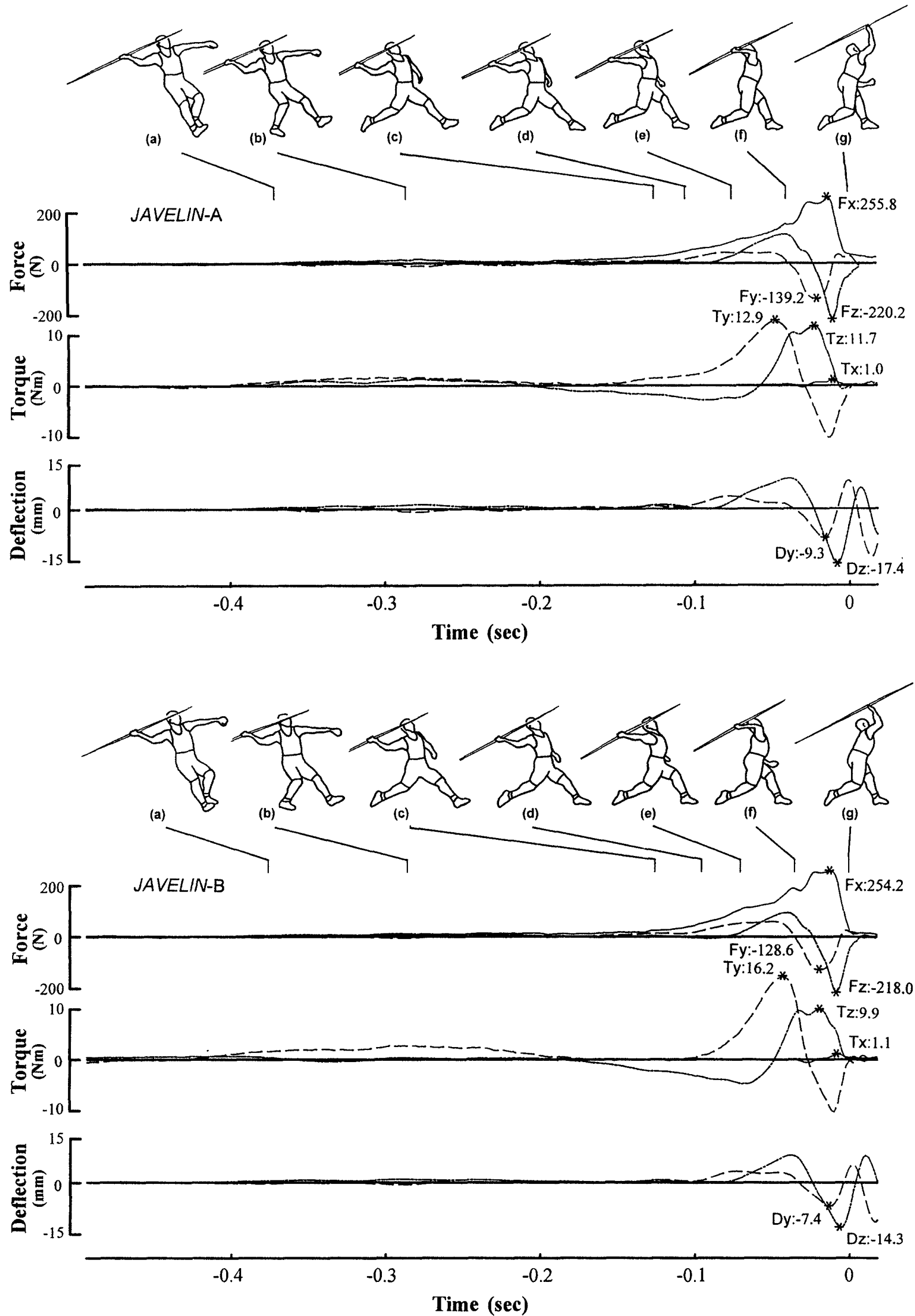

Fig. 4.3 Measured forces in javelin throwing. (Subj. K.K) 
ヤリのリリース，すなわち(g)の瞬間を0として リリースむでの時間を示している，な拉，各デー タは 5 点移動平均により平滑化している.

\section{1 ヤリに加わる力の解析}

\section{1 .1 長軸方向への力}

一般に投げの主動作は，左足着地(c)からリリ 一ス $(\mathrm{g})$ までとされ5), 主にこの間にヤリを加速 すると言われているが，主動作に先立って助走 （クロスステップを含む）が行われており，双方 の動作のつながりから左足着地をきっかけにヤリ が加速され始めるとは考えにくい，測定結果で は，Fig. 4.1-Fig. 4.3でもわかるようにいずれの 被験者に打いても，ヤリの長軸方向の力 Fxは (c)より前の (b)加緩やかに上昇し始めている ことがわかる．(a)から(c)までの動作局面は，助 走から投げ，リリースに至る行程の切り替えとし て重要な役割を果たしている動作であろうと考え られる10).

$\mathrm{Fx}$ はいずれの被験者も最大值に達する直前の (f) 付近において，一時的に停滞や低下が認めら れる。これは連続画からみて，上腕部を加速する 局面から前腕部を加速する局面への切り替え期に 一致する。.やり投げの投げ動作として，体幹部か ら上腕部, 前腕部へ上末端部へ順に連続して加速 していくというムチ動作が有効である3,9) といわ れているが，Fxの一時的な低下は，腕のム千的 な動作に抢ける身体各部の動きに円滑さを欠いた ことに起因するものと推察される．本研究の被験 者より上級レベルの競技者であれば，上腕部から 前腕部への力の伝達が，より円滑になり， Arbeit et al.1)の言うように Fx は最大值まで停滯 なく急激に増加して, 最大值に達するような曲線 になるのかもしれない，

\section{1 .2 長軸まわりのトルク}

Fig. 4.1-Fig. 4.3中の Txはヤリの長軸まわり のトルクを示しているが，いずれの被験者もリリ 一ス前の (e) 付近で低下した後，(f)付近で最高值 に達するという傾向が認められる，絶対值は正の 方向，すなわちヤりを後方から見て，時計まわり に回転させようとするトルクが反時計まわりのト
ルクよりも大きいという結果である．これは連続 画からみて，肘を一旦巻き込むように（肩の外転 - 外旋及び前腕の回内）して反時計回りの方向に ヤリを回転させた後, 腕を振り切って時計回りに 回転させようとする動き4)に相当するものとみら れる。

このように投げ動作では，腕を振りきることに よってヤリは時計まわりに回転をし始める4，リ リース時のヤリのスピン（回転速度）は, 飛行に 影響を与える変量の一つとして考えられてい る5,15)が，本研究の Tx の測定結果からこれを求 めることができる．Txはヤリの長軸まわりのト ルクであるから，長軸まわりの慣性モーメント $\mathrm{I}_{\mathrm{L}}$ と長軸まわりの回転角加速度 $\dot{\omega}$ との間に

$$
\mathrm{Tx}=\mathrm{I}_{\mathrm{L}} \cdot \dot{\omega}
$$

の関係が成立する.上式から回転角速度 $\omega$ は, Tx を慣性モーメント $\mathrm{I}_{\mathrm{L}}$ で除し，回転角加速度 $\dot{\omega}$ を時間積分して求めることができる。これを 計算してみると66.7-140.4 rad/s（10.6-22.3 rps に相当）の範囲であり，映像による分析から得た Terauds が報告した初期回転数（10-25 rps) ${ }^{15)}$ と 同程度の值であった。ヤリの長軸なわりの回転数 を測定する場合，ヤリの最大直径が $3 \mathrm{~cm}$ と非常 に小さいにもかかわらず，ヤリの移動距離が大き いのでリリース時のヤリの映像分析から求めよう とすることは極めて困難である，一方，本研究で 提案した方法は実験で使用するのが競技用のヤリ ではないので，回転角速度が飛距離に影響する変 量であったかを考察することができないという問 題はあるものの，リリ一ス時のヤリの回転速度を 従来の方法より精度よく求め得る方法であると考 えられる。

\section{1 .3 ヤリの短軸方向に加わるカ, トルク及び 短軸方向のたわみ}

ヤリの長軸に対して垂直な方向（以後，短軸方 向と記す）に加わる力及び短軸方向のたわみを Fig. 5 に，短軸まわりのトルクを Fig. 6 に，そ れぞれ合成べクトルの軌跡として示す. Fig. 4 と 同様に Fig. 5, Fig. 6 中の (e)-(g)の符号はそれぞ れの動作局面を示しており，(g)がヤリのリリー ス局面である. Fig. 5 の縦軸 $\mathrm{Fz}, \mathrm{Dz}, \mathrm{T} z$ と横軸 
Fy, Dy, Ty は Fig. 1 に示す軸であり，測定用ヤ リに固定の軸である。

Fig. 5 より短軸方向の力は被験者間で差がある ものの，抢抢むね棈円状で変化して抢り，(e)か ら $\mathrm{g}$ )の区間で力の方が反転し, 後半のリリー 又時に近い区間の方が絶対值が大きいことが認め られる。すなわち，ヤリの短軸方向に対して作用

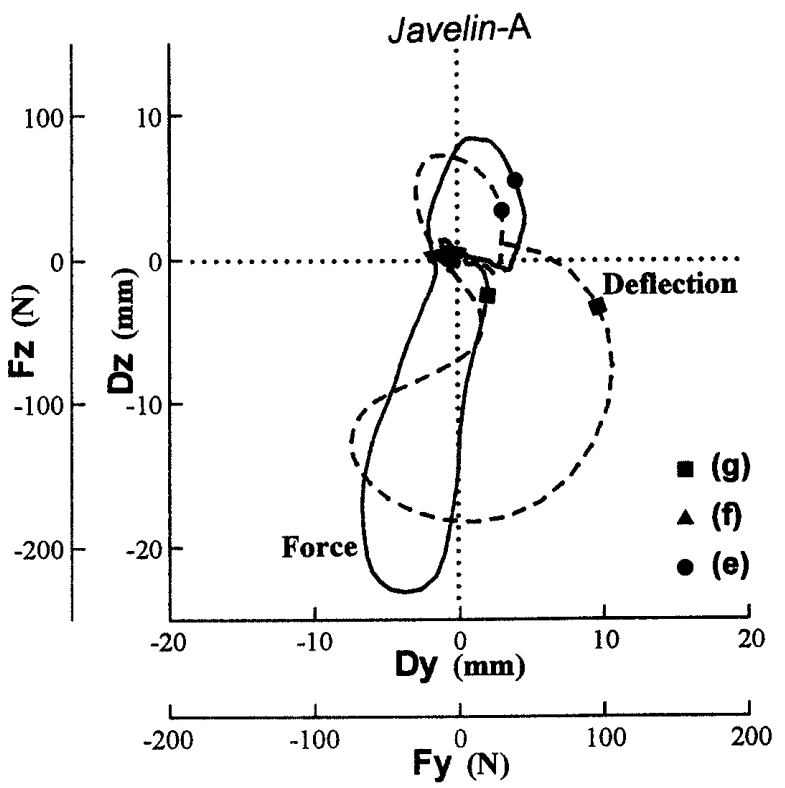

する力は 1 方向で反転（往復）するようなパタ ーンが支配的であると考えられる。

短軸丈わりのトルク $\mathrm{Ty}, \mathrm{Tz}$ はヤリの違いより 競技者で大きく異なることがわかる．M.M では 值が全体的に小さく，K.Kはリリース前に大き い傾向である (Fig. 6 参照).

Ty $\mathrm{T} z$ はカセンサの中心まわりのトルクで

(1) Subj. M.M
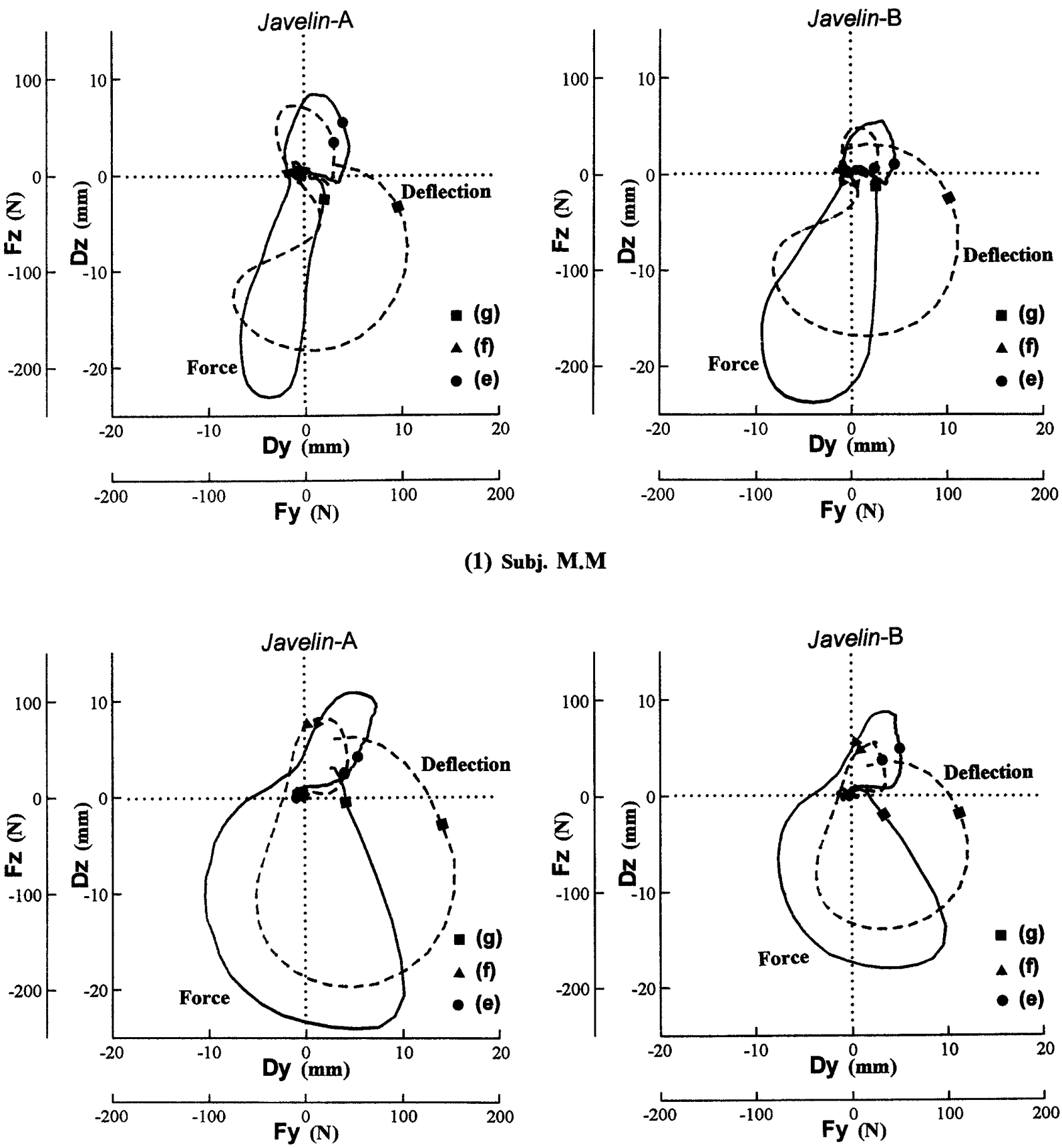

(2) Subj. Y.M 

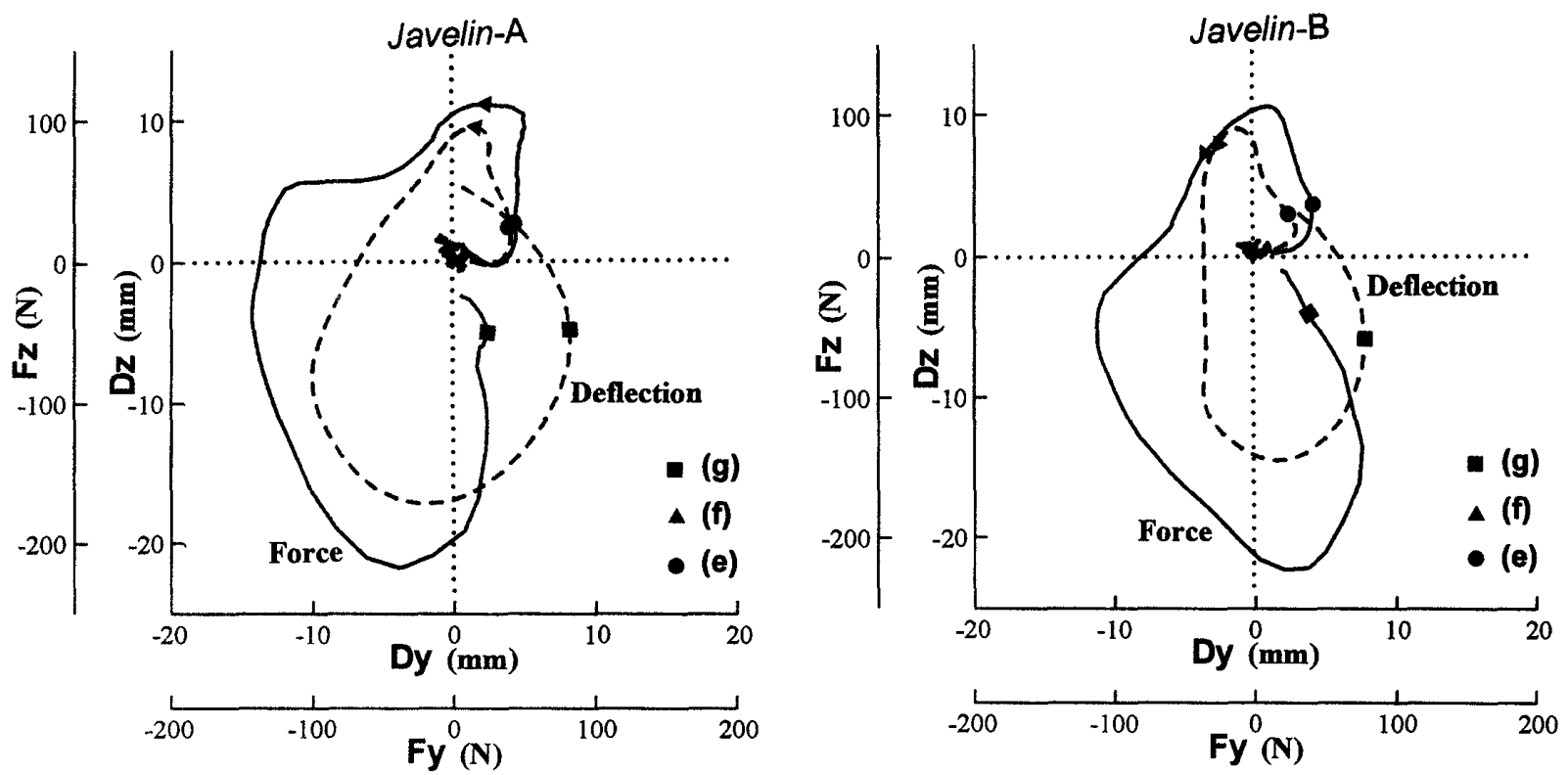

(3) Subj. K.K

Fig. 5 Forces applied to the javelin and deflections of the javelin. (vector diagram)
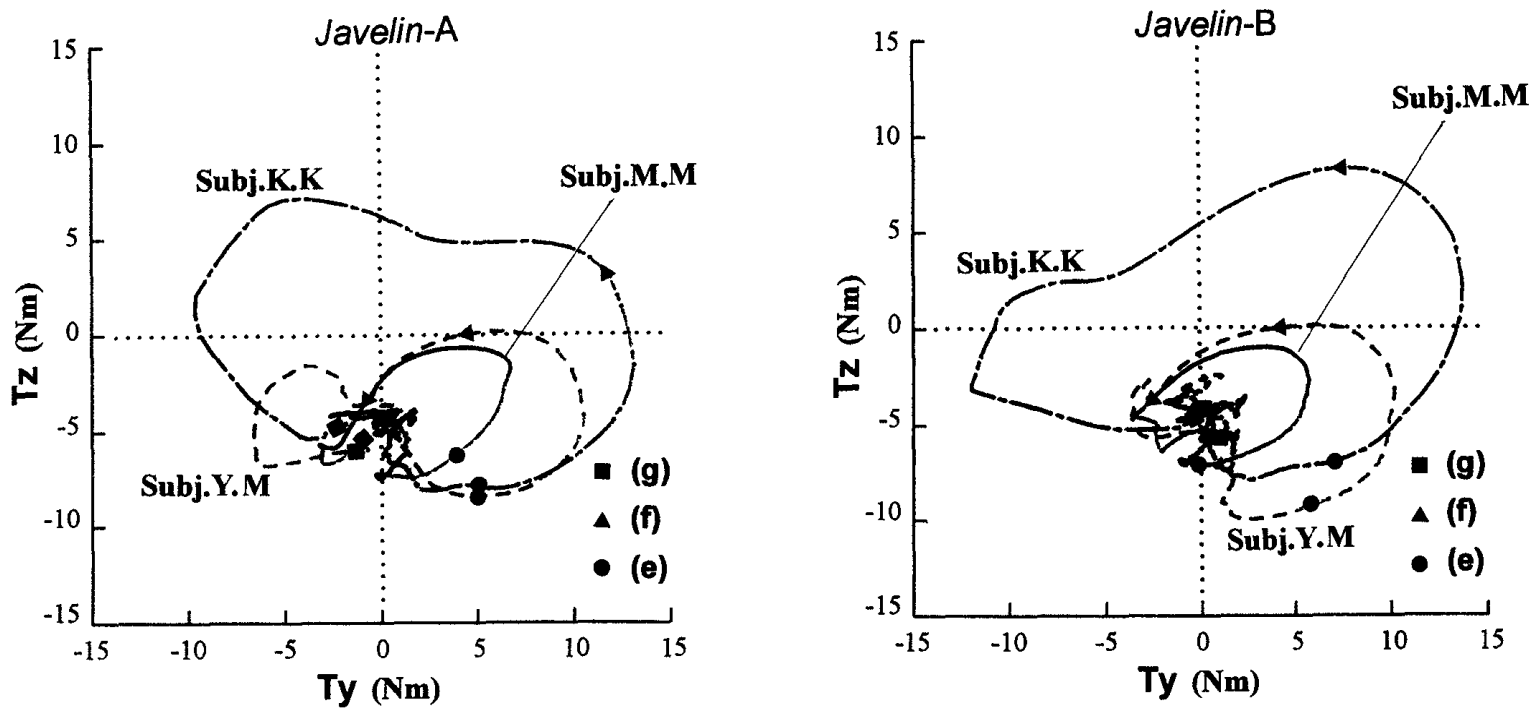

Fig. 6 Torques applied to the javelin. (vector diagram)

ありヤリの重心を通る短軸まわりのトルクでは ない、ヤリの重心を通る短軸まわりのトルクベク トル $\mathrm{T}_{\mathrm{G}}$ 洁,

$$
\mathrm{T}_{\mathrm{G}}=\mathrm{Fyz} \cdot l-\mathrm{Tyz}
$$

Fyz：力センサに加わる力ベクトル（Fyと Fz の合力)
Tyz : カセンサの中心まわりのトルクベクトル (Тyと Tzの合力)

$l: ヤ リ の$ 重心から力センサの中心への位置べ クトル

で表され， $\mathrm{T}_{\mathrm{G}}=0$ であれば，ヤリは向きを変え ようとはしない. 投げ動作中に打け Fyz とlの 


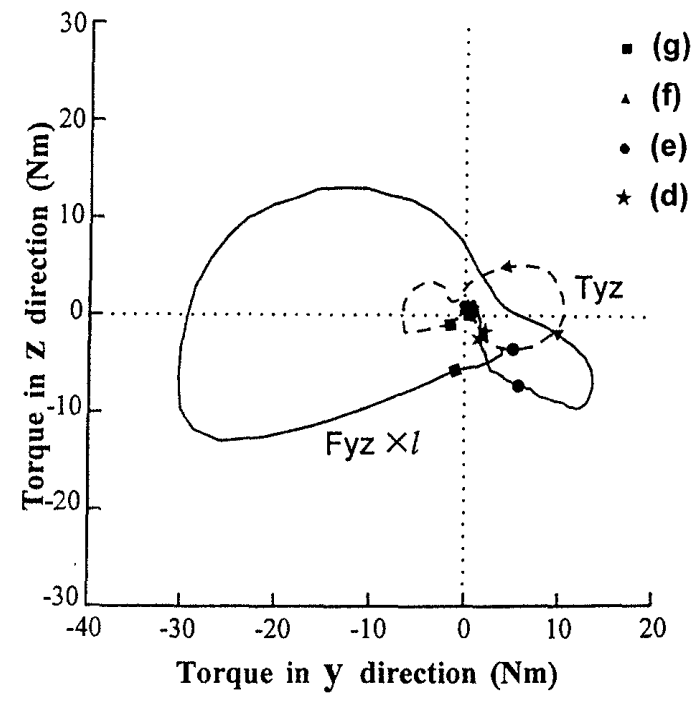

Fig. 7 Torques applied to the sensor and torques around the center of gravity about javelin. (vector diagram)

積及びTyzの変化を Fig. 7 に示す．図中(d)の 頃まで両者はほぼ同じ值で变化しているが，(d) 以後リリースまででは TyzよりもFyz とlの積 の方が大きいことがわかる，特に(f)からリリー スまでは Fyz とlの積の方が極めて大きく，この
間にヤリの重心まわりに回転力が生じていること がわかる、リリー久直前では，Fx最大值に達 していることからもわかるように，競技者はヤリ にできるだけ力を加えようとしている局面であ る.このときのグリップ部の軌道は棈円を描く2) と言われていることから，競技者がヤリにトルク を積極的に与えているのではなく, リリースをで ヤリの長軸方向と手の軌道（動き）が一致しない ために生じるトルクであろうと考えられる。した がって、リリースをでヤリの向きと手の軌道を合 わせるようにすれば，リリース時にヤリの短軸を わりにトルクが生じることは避けられるが，その ために振り切る動作が制約され，競技者は力を加 減して投げ出さなければならなくなるであろう.

\subsection{4 ヤリに加わる力積}

力を時間積分することで力積が得られる．ヤリ の各軸方向への力積をFig. 8 に示す．図中(a)（g)はそれぞれ各動作局面を示している．速度の 変化は力積に比例するので, $\mathrm{x}$ 方向（長軸方向） の力積が大きいほどヤリの飛距離は得やすい，算 出された長軸方向の力積が最も大きかったのは K.K の Javelin-B の時で16.98 Nsであり，この
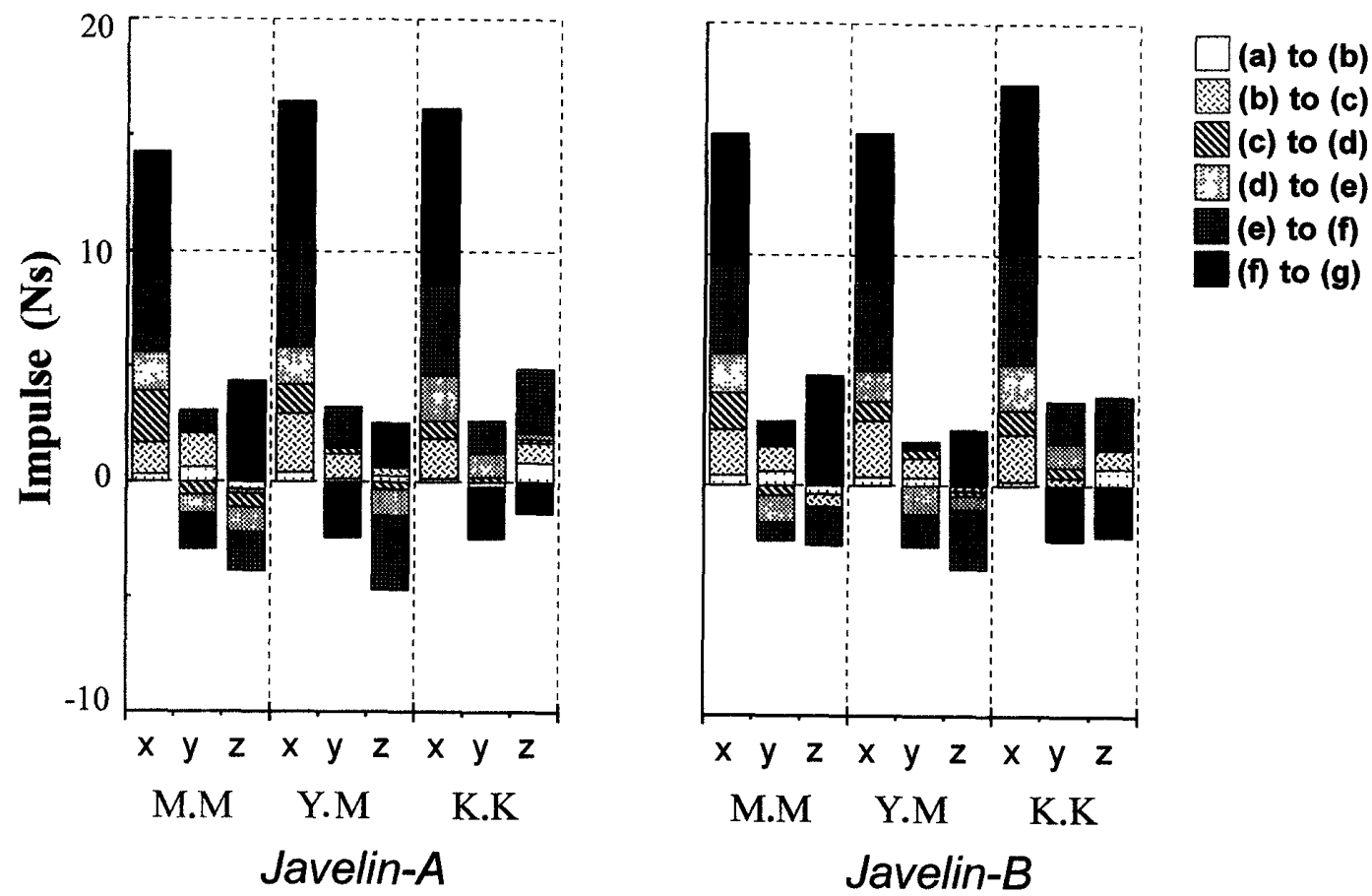

Fig. 8 Impulses applied to the javelin in javelin throwing. 
間にヤリが得た速度は $20.89 \mathrm{~m} / \mathrm{s}$ と計算される. 長軸方向の力積が最も増加するのは，(f)-(g)の 終末局面で，(a)から (g)へリリースに近い局面 ほど力積は大きいことが認められる，中でも(e)(g)の間で得られる力積は投げ動作全体の6070\% (60.3\%: Subj. M.M, Javelin-A - 71.5\%: Subj. K.K, Javelin-A) を占め，この間の動作が重 要であることが同える. 飛距離をさらに増大させ るには，最大值に達するまでスムーズに力を加え ることや，動作の範囲を大きくして力を加える時 間を長くするなどの方法が有効であろうと推察さ れる。

$\mathrm{y}, \mathrm{z}$ 方向（短軸方向）の力積はヤリに迎え角を 生じさせる原因となるので，できるだけ小さい方 が望ましいと考えられる．短軸方向の力積も(e)(f)，(f)-(g)の終末局面において大きいが，(a)一 (f) 間と (f)- ( $\mathrm{g})$ 間では符号が異なっており, 力積 の方向が反対であることが認められる. 最終的に リリース時でのヤリ短軸方向の力積は0.15 (Subj. M.M, Javelin-A) - 3.36 (Subj. K.K, Javelin-A) Ns 程度の範囲である.すなわち，(f) 以後に短軸 方向へ注入される力積はそれまでの方向を抑え る，あるいは修正するという意味のもので，競技 者が能動的に（意図的に）短軸方向への力積を獲 得しようとするものではないものと考えられる。

\section{2 ヤリの弾性が投げ動作に及ぼす影響}

Fig. 4.1-Fig. 4.3においてリリース後には, 力 の 6 成分は概ね 0 になっているが，たわみの 2 成分は大きな値を示して抢り，ヤリのたわみ振動 が残留しながら投げ出されていることがわかる. ヤリのたわみをべクトル線図（Fig. 5）でみる と，1方向を往復するような単純なたわみ方では なく，多方向への複雑なたわみになっていること がわかる．たわみの方向は (e) 付近まで力の方向 と比較的似ているが，以後は異なる挙動である.

Fig. 5, Fig. 6 はヤリに加わる力，トルク及び ヤリのたわみであり，座標軸はヤリに固定された 軸である．したがって，競技者の立場で見るには ヤリが長軸まわりに回転している分（回転角速度 $\omega$ を時間積分して得られる回転角変位）を差し
引き補正する必要がある，助走開始直前のヤリを 保持し構えた時点を初期値として, ヤリが長軸ま わりに回転した分を差し引き，長軸まわりの回転 を考虑したヤリに加わる力，トルク及びヤリのた わみを Fig. 9 に示す.

これでみるとFig. 5 やFig. 6 とはかなり異な り，例えば，ヤリに加わる力は終始，円を描くよ うな挙動（2 方向のたわみ振動が混在している挙 動，長軸方向の移動を考慮すると螺旋状の挙動） になっていることがわかる.このようにヤリに固 定した座標で見た場合と競技者から見た場合とで ヤリに加わる力は明らかに異なっている．このこ とから競技者の立場で考察するには，ヤリに固定 した座標で考えるのではなく，ヤリの長軸まわり の回転を考慮した上で考察する必要があることが 示唆される.これまで，選手がヤリに加える短軸 方向の力やヤリのたわみの挙動は明らかにされて いなかったが，それにもかかわらず，これらを小 さく抑えるように指導が行われてきた ${ }^{17)}$. Fig. 9 に示すように，本手法では，これらの力やヤリの たわみの大きさのみならず，方向と軌跡さえも定 量的に明らかにすることができ，指導するうえで 極めて有益な情報を与えるものと考えられる。

Fig. 5 及び Fig. 6 の結果から，ヤリの短軸方 向に加わる力, トルク及びヤリのたわみに関し て，絶対値が最大に達したときの值，及びその最 大值が出現した時間を Table 3 に示す．最大值は それぞれ y, $z$ 方向の合成ベクトルであり，Fig. 5 やFig. 6 でも明らかなように試技によってその 方向が異なる.

表でもわかるように, ヤリのたわみの最高値は ヤリによって違い，いずれの被験者もJavelin-A の方が值が大きいことが認められる．そして，同 一被験者では短軸方向の力のパターンにはほとん ど差が認められない。これらのことは使用したヤ リの剛性の差であろうと考えられる. 本研究で使 用したヤリは特性が異なり, Javelin-A の方が剛 性が低く, 1 次モ一ドの共振周波数も低い柔らか いヤリである、その分, 加わる力が同じであって む変位が大きい結果となったのであろう。しか し，実験後の被験者の感想に拈いて，一様にヤリ 

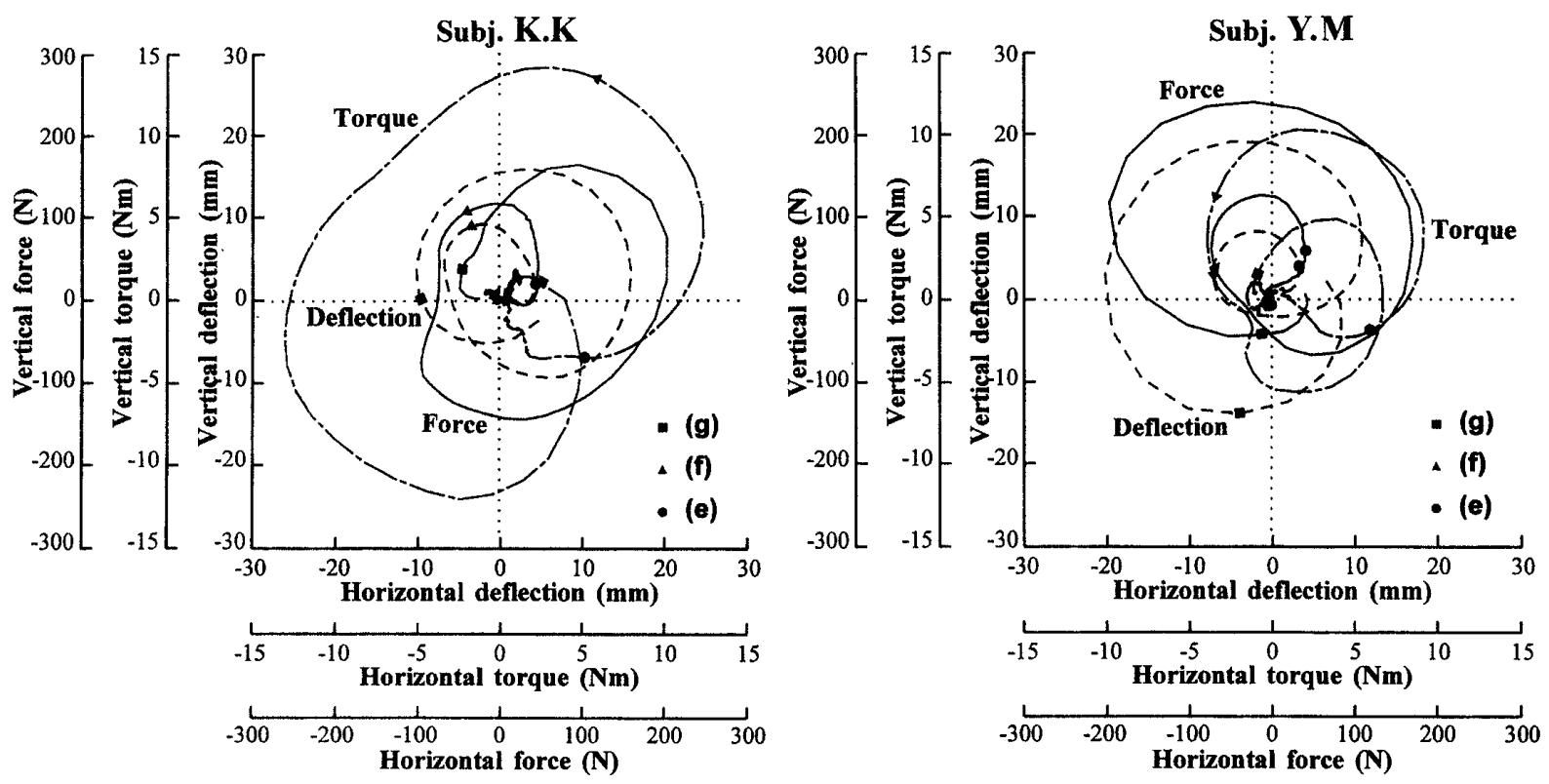

Fig. 9 Forces and torques applied to the javelin and deflections of the javelin considering the rotation around the axial direction of the javelin. (vector diagram)

Table 3 Peakes of the forces and torques applied to the javelin and deflections of the javelin

\begin{tabular}{|c|c|c|c|c|c|c|c|}
\hline & \multirow[b]{2}{*}{ Subject } & \multicolumn{2}{|c|}{ Peak Force } & \multicolumn{2}{|c|}{ Peak Torque } & \multicolumn{2}{|c|}{ Peak Deflection } \\
\hline & & $\underset{(\mathrm{N})}{\text { Value }}$ & $\begin{array}{l}\text { Time } \\
(\mathrm{sec})\end{array}$ & $\begin{array}{l}\text { Value } \\
(\mathrm{Nm})\end{array}$ & $\begin{array}{l}\text { Time } \\
(\mathrm{sec})\end{array}$ & $\begin{array}{l}\text { Value } \\
(\mathrm{mm})\end{array}$ & $\begin{array}{l}\text { Time } \\
(\mathrm{sec})\end{array}$ \\
\hline \multirow{2}{*}{ M.M } & Javelin-A & 232.8 & -0.010 & 7.6 & -0.054 & 18.1 & -0.006 \\
\hline & Javelin-B & 243.5 & -0.011 & 6.4 & -0.056 & 17.1 & -0.006 \\
\hline \multirow{2}{*}{ Y.M } & Javelin-A & 250.8 & -0.007 & 10.7 & -0.047 & 20.7 & -0.005 \\
\hline & Javelin-B & 189.0 & -0.006 & 10.5 & -0.045 & 15.0 & -0.004 \\
\hline \multirow{2}{*}{ K.K } & Javelin-A & 220.9 & -0.010 & 14.4 & -0.040 & 17.4 & -0.009 \\
\hline & Javelin-B & 224.4 & -0.008 & 16.7 & -0.041 & 14.7 & -0.006 \\
\hline
\end{tabular}

の特性の相違は感じなかったと述べているよう に，ヤリの剛性の差によって加わる力の大きさが 変化したり，そのパターンが変容するような筒所 は特に認められていない。むしろ，被験者間の差 の方が大きく，ヤリの剛性の差が直接投げ動作に 影響するまでに至らなかったものと推察される。

本研究では，設定したヤリの剛性の差が投げ動 作に影響するまでに至らなかったが，今後，この 剛性の差をさらに大きくして投げ動作への影響を 確認するとともに，競技者（被験者）のレベルを 広げて多くの競技者について測定を行い，最適な
投げ動作とヤリの動特性について検討を重ねる必 要がある。

\section{4. 結言}

本研究では，やり投げ競技において，ヤリが投 げ出されるまでの間に競技者によってヤリに加え られる動的な力の 6 成分执よびヤリのたわみの 2 成分を測定し，投げ動作及びヤリの挙動につい て力学的分析を行った，本研究によって得られた 知見をまとめると以下の通りである。

1）ヤリの長軸方向に加わる力は最大値に達 
する直前に，一時的に停漁あるいは低下すること が認められた。

2）ヤリの長軸まわりのトルクは，リリース 前に一旦極小值を経過してから最大值に達する傾 向にあり，腕の振り切りに先立って，反対まわり にトルクが生じていることを見い出した。

3）ヤリの短軸方向に加わる力は打打むね 1 方向での変化が支配的であった。

4）力センサに加わるカとトルクから，ヤリ の重心を通る短軸をわりに関してトルクが計算さ れ，リリース直前に大きい值となることを見い出 した.

5）ヤリの長軸方向の力積が最も大きいのは 投げの終末局面で，リリースに近い局面ほど力積 は大きいことが認められた。

6）投げ動作中のヤリのたわみは 1 万向を往 復するようなたわみ方ではなく, 多方向への複雑 なたわみであった。

7）競技者の立場でヤリに加わる力やヤリの たわみを考察するには，ヤリの長軸まわりの回転 量を考慮する必要があることが示唆された。

8）ヤリの剛性の差によってたわみ量には差 が認められたが，加わる力やトルクの大きさが変 化したり，そのパターンが変容するような箇所は 特に認められなかった。

なお，本研究の一部は平成 7 年度文部省科学 研究費奖励研究（A）課題番号07780061の補助 で行われた。

\section{文献}

1) Arbeit, E., Bartonietz, K., Borner, B., Hellmann, K. and Skibbia, W. (1988) The javelin: The view of DVfL of the GDR on talent selection, technique and main training contents of the training phases from beginner to top-level athlete. New studies in ATHLETICS 1: 57-74.

2) Ariel, G. (1975) Principles of ballistic motion in resistance exercise training. Track and Field Quarterly Review 75: 58-61.

3） E.N. マトベーエフ：小野耕三訳（1978）ヤリ投 げ. 陸上競技トレーナー用教科書. ベースボール ・マガジン社 : 東京, pp. 443-462.

4） G. ダイソン：金原 勇・橴川价二・古藤高良訳
（1972）投てき運動の力学. 陸上競技の力学. 大 修館書店 : 東京, pp. 209-249.

5）林幸信（1979）やり投．金原 勇編陸上競技 のコーチング(II)．大修館書店 : 東京, pp. 338343.

6) Hubbard, M. and Bergman, C. D. (1989) Effect of vibrations on javelin lift and drag. Int. J. Sport Biomechanics 5: 40-59.

7) Hubbard, M. (1989) The throwing events in track and field. In: Vaughan, C. L. (Ed.) BIOMECHANICS of SPORT. CRC Press Inc.: Florida, pp. 214-238.

8）池上康男（1982）やり投げ考. Jap. J. Sports Sci. 1: 99-103.

9）金子公有 ·豊岡示朗 - 伊藤 章（1973）槍投げ に打ける“鞭効果”。身体運動の科学 $\mathrm{N}$ スポー ツのバイオメカニクス. 杏林書院 : 東京, pp. 69-79.

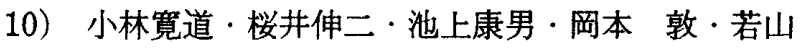
章信・植屋清見 (1992) やり投セッポ・ラテュ選 手の技術分析. 平成 3 年度日本体育協会スポーツ 医・科学研究報告. 日本体育協会 : 237-241.

11）前田正登 - 野村治夫 - 森脇俊道 - 社本英二 （1993）競技用ヤリの動特性. Jap. J. Sports Sci. 12: 130-136.

12）前田正登・野村治夫 - 社本英二 · 森脇俊道 （1994）やり投におけるヤリに加わる力の測定. 体育学研究 39: 109-117.

13）前田正登·野村治夫 · 美崎教正 - 社本英二 ·森脇 俊道・平岡哲也 (1995) やり投げ用 6 軸力セン サの開発. スポーツ工学シンポジウム1995講演論 文集 : 102-106.

14）松井秀治 - 桜井伸二 - 池上康男 - 岡本 敦 - 石田 浩司 ·横坂 貴 - 小林寛道 (1989) やり投げの三 次元的映像分析. スポーツ医・科学 3: 41-46.

15) Terauds, J. (1978) Computerized biomechanical analysis of selected javelin throwers at the 1976 Montreal Olympiad. Track and Field Quarterly Review 78: 25-28.

16) Terauds, J. (1985) BIOMECHANICS OF THE JAVELIN THROW. ACADEMIC PUBLISHERS: California.

17）吉田雅美（1993）ヤリ投げ。最新陸上競技入門 シリーズ 9. ベースボールマガシン社 : 東京.

$\left(\begin{array}{l}\text { 平成 } 8 \text { 年 } 9 \text { 月 } 12 \text { 日受付 } \\ \text { 平成 } 9 \text { 年 } 6 \text { 月 } 21 \text { 日受理 }\end{array}\right)$ 